material and of the process of evolution. Behind Muller's achievement lay the primary disclosure of the chromosome mechanism of heredity by E. B. Wilson (to whom Muller gave chief credit), T. H. Morgan and his students; after it came the detailed development of cytogeneties and the molecular basis of heredity. Muller participated actively in both the practical experimental and the theoretical development of genetics for more than fifty years, and left on it the indelible stamp of his ideas and vigorous personality.

He left Texas for Moscow in 1933 (he had taken the first cultures of Drosophila there in 1922), but abandoned the Soviet Union in 1937 to work first at the University of Edinburgh until 1940, then at Amherst College until taking up his professorship at Indiana in 1945.

Muller made important contributions to human genetics and to evolutionary theory through development of the classical theory of population structure (genetic load of mutations), and devoted increasing attention and enthusiasm to proposals for human betterment through control of human reproduction.

Throughout his work there runs a pattern of persistent use of mechanistic interpretations of biological phenomena. The success of these interpretations in genetics, as in physics and chemistry, led to an attitude of confidence which in Muller's case became overt optimism regarding the prospect of ultimate control by man over his own destiny.

L. C. Dunn

\section{Professor F. A. Vening Meinesz}

Felix Andries Vening Meinesz, former professor of cartography and geodesy, and later also of geophysics, at the University of Utresht from 1927 to 1957, and professor of geodesy at the Technological University, Delft, from 1939 to 1957, died in Amersfoort on August 10, 1966. He had been in hospital for six weeks after a fall at his home which caused a fractured hip; he was 79.

Vening Meinesz obtained his degree in civil engineering from the Technological University at Delft in 1910 . Soon afterwards he was appointed engineer of the Netherlands Geodetic Commission and was commissioned to carry out pendulum observations in the Netherlands. This was a turning point which was to influence his whole career. On land he did pioneering work in this field, which he later repeated at sea. He was able to eliminate the disturbances caused by the irregular movements of the weak soil of the Netherlands by the so-called "twopendulum method", and in 1915 he published the theory of his method in the thesis for his doctorate, entitled "Bijdrage tot de theorie der slingerwaarnemingen", after which he received his doctorate cum laude. In 1923 his "Observations de pendule dans les Pays-Bas" were published, describing the application of this method for fifty stations in the Netherlands. At this time Vening Meinesz was beginning to wonder whether this twopendulum method could be applied with sufficient accuracy at sea as well. Tests made it clear that it would be difficult to fulfil the conditions of this method (equal amplitude and opposite phases of the pendulums) even in a submerged submarine. Vening Meinesz then realized that, independent of amplitude and phase, the difference in the angle of elongation of two isochronous pendulums, swinging in the same plane, was insensitive to horizontal accelerations, and that this angle could be regarded as the angle of elongation of a fictitious pendulum with the same period as the original pendulums. This method was worked out theoretically and instrumentally in his "Theory and Practice of Pendulum Observations at Sea" (1929), and it was used during the many submarine voyages which made him so well known. The results of all these voyages were published in the four volumes of Gravity Expeditions at Sea.
In the meantime Vening Meinesz published, in 1928, "A Formula Expressing the Deflection of the Plumbline in the Gravity Anomalies and some Formulae for the Gravity-field and the Gravity-potential Outside the Geoid", which became familiar to geodesists. His extensive gravimetric observations in the Indonesian Archipelago made it possible for this method to be applied for the first time at sea by Dr J. E. Baron de Vos van Steenwijk in his "Plumbline Deflections and Geoid in Eastern Indonesia as derived from Gravity".

Vening Meinesz continually emphasized the relationship between geodesy and geophysics. As a convinced supporter of isostasy, he tried to gather all possible information on the deviations from the state of equilibrium in the Earth. Combining this information with geological and seismological data, he always tried to make the geodesist better acquainted with the background to his science. He paid special attention, however, to trying to explain the reason for the irregular form of the Earth's crust. He considered that convection currents in the Earth's mantle were mainly responsible for the movements and consequent displacement of the continents. He was always able to express very difficult physical problems mathematically, as he had already done with the pendulum theory.

All those who knew Vening Meinesz were impressed not only by his great scientific knowledge, but also by his friendliness and hospitality, and his readiness to exchange ideas. He was awarded many Dutch and foreign decorations, honorary doctorates and the membership of many learned societies. One of his most important Dutch decorations was the "Eremedaille in Goud voor Voortvarendheid en Vernuft van de Huisorde van Oranje".

G. J. Bruins

\section{George Smith}

George SMIth, who died on March 29, 1967, at the age of 71 , started his career as a chemist. He graduated from Manchester University in 1916 and obtained his M.Sc. and A.I.C. in 1918. As chemist to a cotton manufacturing firm he met early the problem of mildew on cotton goods, and this led to the study of moulds, which was to become his chief work. In 1930 he joined Professor H. Raistrick at the London School of Hygiene and Tropical Medicine, where he remained till his retirement in 1961. Here he began with studies of the biochemistry of mould products, but become more and more involved in the taxonomy and care of the fungal cultures. During the Second World War he investigated the tropic proofing of military and naval equipment and thus became one of the first specialists in the field of bio-deterioration of materials. On retirement he continued his work on moulds at the Commonwealth Mycological Institute.

In 1939 he produced the first edition of An Introduction to Industrial Mycology. This book, with its magnificent photomicrographs, gathered together the information, much of it original, which hitherto scientists working in industry had found difficult to obtain. It is now generally used as an introduction to mycology for all those interested in moulds and moulding. Besides many short papers on the taxonomy, particularly of Penicillium and Aspergillus species, he produced monographs on the genera Paecilomyces and Scopulariopsis. All his work was undertaken with painstaking care and a meticulous attention to detail.

He enjoyed field work and was foray secretary of the British Mycological Society for some years, and was president of this society in 1946.

He was a quiet retiring man, kind and considerate, with diverse interests, covering all branches of science and philosophy. His favourite relaxation was music and he was an accomplished performer.

Agnes H. S. OnIons 